\begin{tabular}{|l|l|l|l|l|l|}
\hline J. Tek. Ling. & Vol. 10 & No. 1 & Hal. 77 - 84 & Jakarta, Januari 2009 & ISSN 1441-318X \\
\hline
\end{tabular}

\title{
PENELITIAN AIR TANAH DI WADUK PUNTUK SURUH KECAMATAN PENGADEGAN KABUPATEN PURBALINGGA - JAWA TENGAH
}

\author{
Wahyu Garinas \\ Peneliti di Pusat Teknologi Sumberdaya Mineral \\ Badan Pengkajian dan Penerapan Teknologi
}

\begin{abstract}
Based on groundwater indication map, the area of Pengadegan district, Purbalingga Regency, has low groundwater resources potential for both deep and shallow groundwater.

Investigation using resistivity showed that the potential water layers were found in the eastern part of the Dam at $B$ and $C$ layers. The groundwater is shallow and the thickness of the aquifer is about 20 meter and extent horizontally up to 30 meter. Layer $A$ and $B$ in the western part of the Dam are possibly act as a water trap as they lies above a compact layer $E$.

To know the potential groundwater area it is suggested that further research and survey be done in the eastern part of the Dam.
\end{abstract}

Key words : water resources, imaging resistivity, potential

\section{PENDAHULUAN}

\subsection{Latar Belakang}

Kecamatan Pengadegan merupakan salah satu 18 kecamatan yang termasuk dalam Kabupaten Purbalingga, Propinsi Jawa Tengah, Gambar 1. Daerah ini pada umumnya berupa daerah perbukitan dan dataran yang umumnya merupakan daerah cukup kesulitan air. Pada musim kemarau terutama pada daerah perbukitan dan daerah waduk disekitarnya mengalami kekurangan persediaan air. Waduk ini berfungsi sebagai tempat lokasi cadangan air dan merupakan salah satu tempat tujuan dan daerah wisata air. Sebagai sumber air alternatif lainnya terdapat beberapa lokasi mata air cukup penting yang biasanya berupa sumur.

Pada musim kemarau dampak yang paling sering dirasakan oleh masyarakat adalah cukup sulitnya mendapatkan air bersih. Pemerintah daerah memang telah

memanfaatkan air dari waduk yang lainnya untuk memenuhi masyarakat, akan tetapi masih belum seluruhnya mendapatkan air bersih. Daerah tangkapan air yang menjadi andalan masyarakat umumnya akan kekurangan debit pada musim kemarau. Pemerintah daerah Kabupaten Purbalingga memiliki kepentingan dengan adanya Waduk Puntuk Suruh ini selain sebagai tempat daerah tangkapan air juga sebagai tempat tujuan wisata air. Pembangunan waduk penampungan air cukup penting keberadaannya sehingga pemerintah daerah akan dapat memanfaatkannya secara optimal sesuai dengan tujuan pembangunannya.

Seiring dengan berubahnya kondisi alam sekitar waduk, maka dampak yang telah dirasakan adalah semakin 
berkurangnya jumlah air. Hal ini dapat terlihat misalnya dari semakin menurunnya ketinggian muka air di dalam waduk dan untuk jangka panjang dikhawatirkan akan kering apabila musim kemarau yang cukup lama.

Penelitian potensi ketersediaan air di waduk ini dilakukan dalam rangka mengetahui gambaran umum apakah pembangunan waduk berada pada lokasi potensi sumberdaya air. Selain itu diharapkan pula akan dapat memberikan masukan kepada pemerintah daerah dimana lokasi-lokasi potensi air tanah di sekitar waduk sehingga nantinya jumlah air di dalam waduk tidak sampai habis pada musim kemarau.

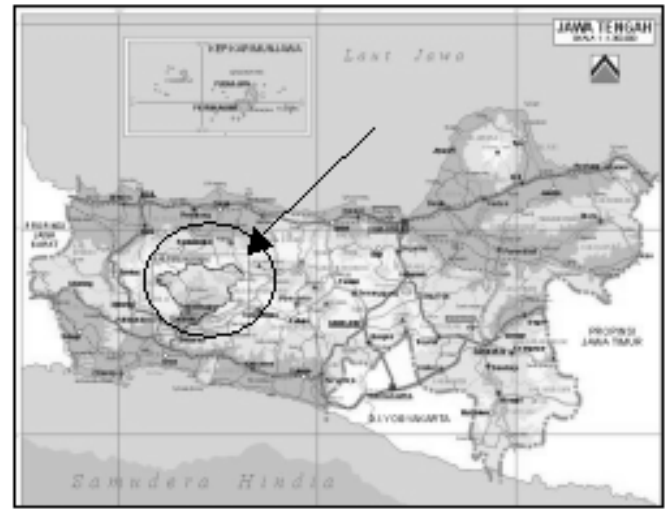

Gambar 1. Lokasi Kabupaten Purbalingga Propinsi Jawa Tengah ${ }^{1)}$

\subsection{Kondisi Geografi dan Topografi. ${ }^{1)}$}

Kecamatan Pengadegan merupakan salah satu dari kecamatan di Kabupaten Purbalingga. secara administratif daerah ini berbatasan dengan : sebelah utara Kecamatan Rembang, sebelah selatan Kecamatan Kejobong, sebelah timur Kabupaten Banjarnegara dan di sebelah barat Kecamatan Kali Gondang. Gambar 2.

Topografi Kabupaten Purbalingga terdiri atas dataran tinggi, dataran rendah, perbukitan dan sebagian merupakan daerah lereng Gunung Slamet terbagi , menjadi dua wilayah yaitu :

1. Wilayah Utara, merupakan dataran tinggi yang berbukit - bukit dengan kelerengan mencapai $40 \%$, meliputi Kecamatan : Kutasari, Bojongsari, Mrebet, Bobotsari, Karangreja, Karangjambu, Karanganyar, Kertanegara dan Rembang.

2. Wilayah Selatan : merupakan dataran rendah dengan kemiringan antara $0 \%$ $25 \%$ yang wilayahnya meliputi Kecamatan : Purbalingga, Kalimanah, Padamara, Kemangkon, Bukateja, Kejobong, Pengadegan, Kaligondang, sebagian Kutasari, Bojongsari dan Mrebet.

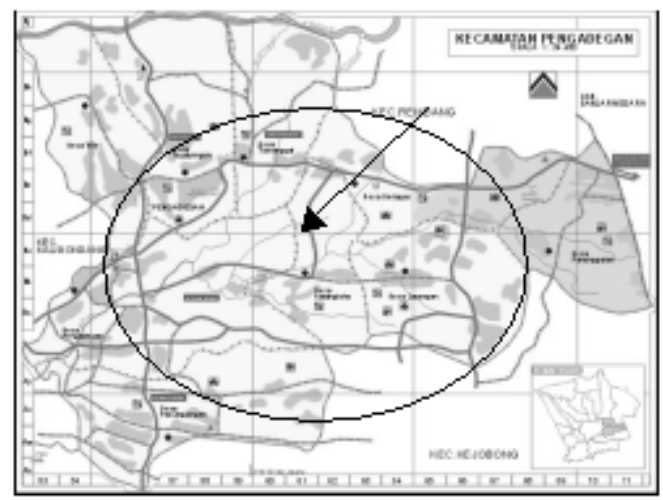

Gambar 2. Lokasi kecamatan Pengadegan Kabupaten Purbalingga, ${ }^{1}$.

\subsection{Iklim $^{1)}$}

Secara umum iklim di wilayah kabupaten Purbalingga dibagi kedalam wilayah iklim yaitu :

1). Wilayah Utara terletak di kaki Gunung Slamet dengan ketinggian berkisar antara 400 - 1.124 meter dari permukaan air laut. Temperatur antara $22-32^{\circ} \mathrm{C}$, dengan curah hujan mencapai $3.500-4.500 \mathrm{~mm}$ tahun, yang meliputi kecamatan : Kutasari, sebagian Bojongsari, sebagian Mrebet, Karangreja, Karangjambu, Bobotsari, Karanganyar, Kertanegara, dan Karangmoncol. 
2). Wilayah Selatan dengan ketinggian tempat berkisar antara $42-116 \mathrm{~m}$ dari permukaan air laut. Temperatur antara 28 $32{ }^{\circ} \mathrm{C}$ dengan curah hujan mencapai 2.500 - $3.500 \mathrm{~mm}$ setiap tahun, yang meliputi kecamatan : Kejobong, Pengadegan, Kaligondang, Kemangkon, Bukateja, Kalimanah dan Padamara.

\subsection{Tujuan Penelitian}

Tujuan dilakukannya penelitian ini adalah untuk mengidentifikasi kondisi air bawah tanah disekitar waduk Puntuk Suruh sehingga akan diketahui potensi air untuk keperluan di waduk. Selain itu untuk mengetahui apakah lokasi pendirian waduk berada pada daerah sumber air seperti yang diharapkan.

\section{METODE PENELITIAN}

Pelaksanaan penelitian air tanah di kecamatan Pengadegan meliputi kegiatan:

\subsection{Identifikasi dan pengumpulan data untuk penentuan lokasi penelitian}

Pada tahapan ini dilakukan identifikasi sumberdaya air meliputi tingkat pemanfaatan, penyebaran secara regional dari data sekunder maupun survei lapangan, laporan mengenai pendataan terdahulu, laporan hasil kajian, dan informasi lainnya. Data sekunder lain yang dikompilasi antara lain : peta geologi, hidrologi dan peta tematik lainnya skala $1: 25.000$. dari data tersebut di atas maka dilakukan penentuan titik lokasi pengambilan data Imaging resistivity.

\subsection{Pengambilan data dalam rangka penelitian potensi sumberdaya air}

Kegiatan yang dilakukan antara lain pengambilan data dilapangan untuk mengetahui kondisi umum lokasi penelitian. Selanjutnya melakukan resistivity imaging (geolistrik) di areal yang diperkirakan kesulitan air seperti disekitar daerah Mesjid Miftahul Jannah atau di pemukiman penduduk yang mengalami kesulitan air bersih.

\subsection{Interpretasi Hasil Lapangan}

Tahapan berikutnya melakukan interpretasi data sehingga diketahui daerah yang berpotensi. Secara teori, besaran yang diukur pada metoda geolistrik ${ }^{4}$ adalah potensial listrik dan kuat arus, sedangkan yang dihitung adalah tahanan jenis.

Potensial listrik didefinisikan sebagai energi potensial $(U)$ per satuan muatan uji $(Q)$, atau ekspresi matematisnya adalah :

$$
U \int_{\infty}^{r}=\mid E . d r=\frac{1}{4 \pi \varepsilon} \frac{Q}{r}(\mathrm{i})
$$

pada persamaan tersebut ;

$U=$ Energi potensial

$E=$ medan listrik

$Q$ = gaya coloumb

nå = konstanta

$r=$ jarak antar muatan

Arus listrik adalah gerak muatan negatif (elektron) pada materi dalam proses mengatur diri menuju keseimbangan. Peristiwa ini terjadi bila materi mengalami gangguan karena adanya medan listrik. Bila medan listrik arahnya selalu tetap menuju ke satu arah, maka arus listrik yang mengalir akan tetap juga arahnya. Arus listrik yang mengalir searah disebut DC (Direct Current) sedangkan yang mengalir bolak-balik disebutAC (Alternating Current). Hubungan antara arus listrik dengan muatannya, secara matematis dituliskan sebagai berikut :

$$
I=\frac{d Q}{d t} \quad(\text { ii })
$$

Menurut Hukum Ohm, hubungan antara besarnya beda potensial listrik (V), kuat arus (I) dan besarnya tahanan kawat penghantar adalah :

$$
\text { ( iii ) }
$$

Pada metoda geolistrik $1 \mathrm{D}$, pembahasan mengenai aliran listrik dalam bumi didasarkan pada asumsi bahwa bumi 
merupakan medium homogen isotropis. Jadi, lapisan batuan di bawah permukaan bumi diasumsikan berbentuk berlapis-lapis. Pada survei geolistrik dipakai 2 (dua) sumber arus. Dengan demikian arah arus listrik dan equipotensialnya adalah : persamaan tersebut baru menghasilkan nilai tahanan jenis dan kedalaman semu. Untuk mendapatkan nilai tahanan jenis dan kedalaman sebenarnya dipakai pemodelan inversi 2D.

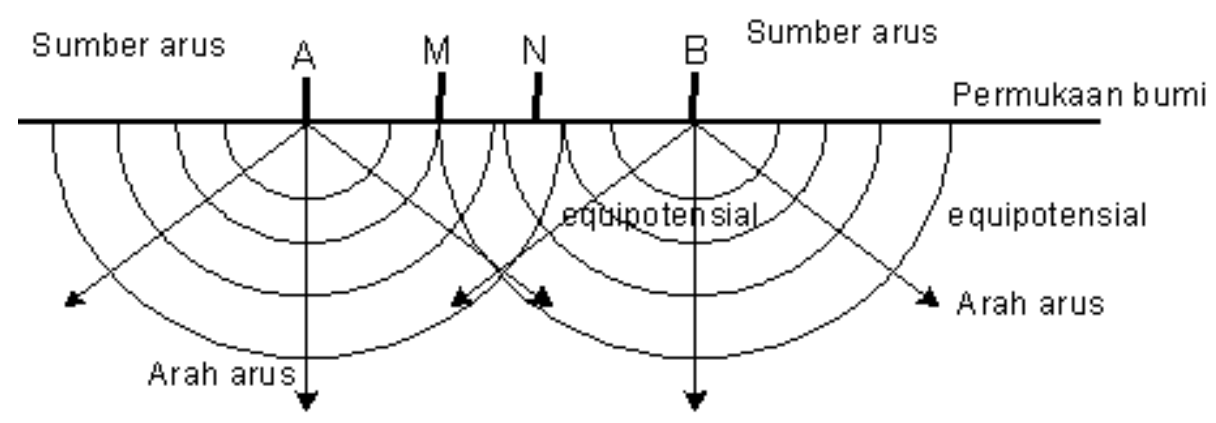

Gambar 2. Arah Arus Listrik dan Garis Equipotensial untuk Dua Sumber Arus Berada di Permukaan Bumi.

Dari gambar diatas dua sumber arus digambarkan sebagai titik $A$ dan $B$, sedangkan pengukuran beda potensial dilakukan di titik $\mathrm{M}$ dan $\mathrm{N}$.

Konfigurasi (susunan) elektroda arus dan potensial pada geolistrik 2D berbeda dengan geolistrik 1D. Pada geolistrik 2D, susunannya adalah sebagai berikut :

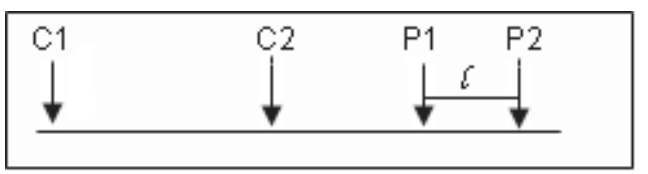

Gambar 3. Konfigurasi elektroda arus dan potensial pada geolis-trik 2D, metoda pole - dipole. Jarak $\mathrm{P} 1-\mathrm{P} 2$ selalu $C, \mathrm{n} 1=$ pengukuran ke $-1, \mathrm{n} 2=$ pengukuran ke -2 , dst.

Pada pengukuran geolistrik $2 \mathrm{D}$, persamaan menjadi :

$\mathrm{pa}=\mathrm{pn}(\mathrm{n}+1) / \mathrm{R}$

Persamaan (iv) selanjutnya dipakai untuk mengolah data hasil pengukuran geolistrik 2D. Perhitungan menggunakan
Data hasil penelitian didapatkan dari pengamatan dilokasi lapangan dan interpretasi dengan bantuan software serta hasil survei kondisi permukaan.

\section{HASIL DAN PEMBAHASAN}

\subsection{Hasil Identifikasi daerah penelitian.}

\subsubsection{Curah Hujan}

Iklim dan cuaca di Kabupaten Purbalingga secara umum sama dengan daerah lainnya di Indonesia yang terbagi atas musim hujan dan kemarau. Data curah hujan yang terjadi di daerah Kabupaten Purbalingga dari hasil pengukuran 10 stasiun pada tahun 2005 tinggi pada curah hujan bulan pada bulan Desember dengan rata-rata hujan sebesar $671 \mathrm{~mm}$ dengan 19 hari hujan. Sedangkan curah hujan terendah pada bulan Agustus dengan rata-rata $72 \mathrm{~mm}$ dengan 4 hari hujan. Secara umum daerah penelitian Kecamatan Pengadegan termasuk kedalam daerah dengan curah hujannya yang tidak terlalu besar. 


\subsubsection{Lingkungan Daerah Aliran Sungai}

Lingkungan di sekitar daerah aliran sungai di Kabupaten Purbalingga hampir semuanya dimanfaatkan oleh masyarakat sebagai sumber air. Terdapat sekitar 3 (tiga) buah sungai Serayu, Klawing dan Kacangan. Sungai-sungai tersebut kecuali Serayu termasuk kedalam kategori sedang dan dimanfaatkan umumnya masyarakat untuk keperluan sehari-hari.

Pemanfaatan daerah sekitar sungai tentunya akan mempengaruhi kondisi sungai. Perusakan akibat aktifitas seperti penambangan disekitar sungai akan mempegaruhi ketersediaan air pada umumnya. Oleh karena itu potensi kerusakan di daerah aliran sungai di Kabupaten Purbalingga sangat besar terutama oleh aktifitas penambangan pasir.
Potensi air permukaan yang menjadi sumber penting bagi penduduk di sekitar sungai perlu tetap dijaga dengan upaya menjaga terhadap kerusakan lingkungan sumber air.

\subsubsection{Sumberdaya air}

\section{Air permukaan}

Air permukaan di wilayah Kecamatan Pengadegan umumnya diperoleh dari sungai yang ke mudian berfungsi mengumpulkan air hujan kedaerah aliran sungai. meresap ke dalam tanah dan sisanya mengalir ke sungai sebagai air permukaan. Hampir semua sungai di Kecamatan Pengadegan dapat dimanfaatkan sebagai sumber air oleh masyarakat sekitarnya. Penduduk di daerah ini memperoleh air dari sumur gali yang dalamnya sekitar $10-15$ meter.

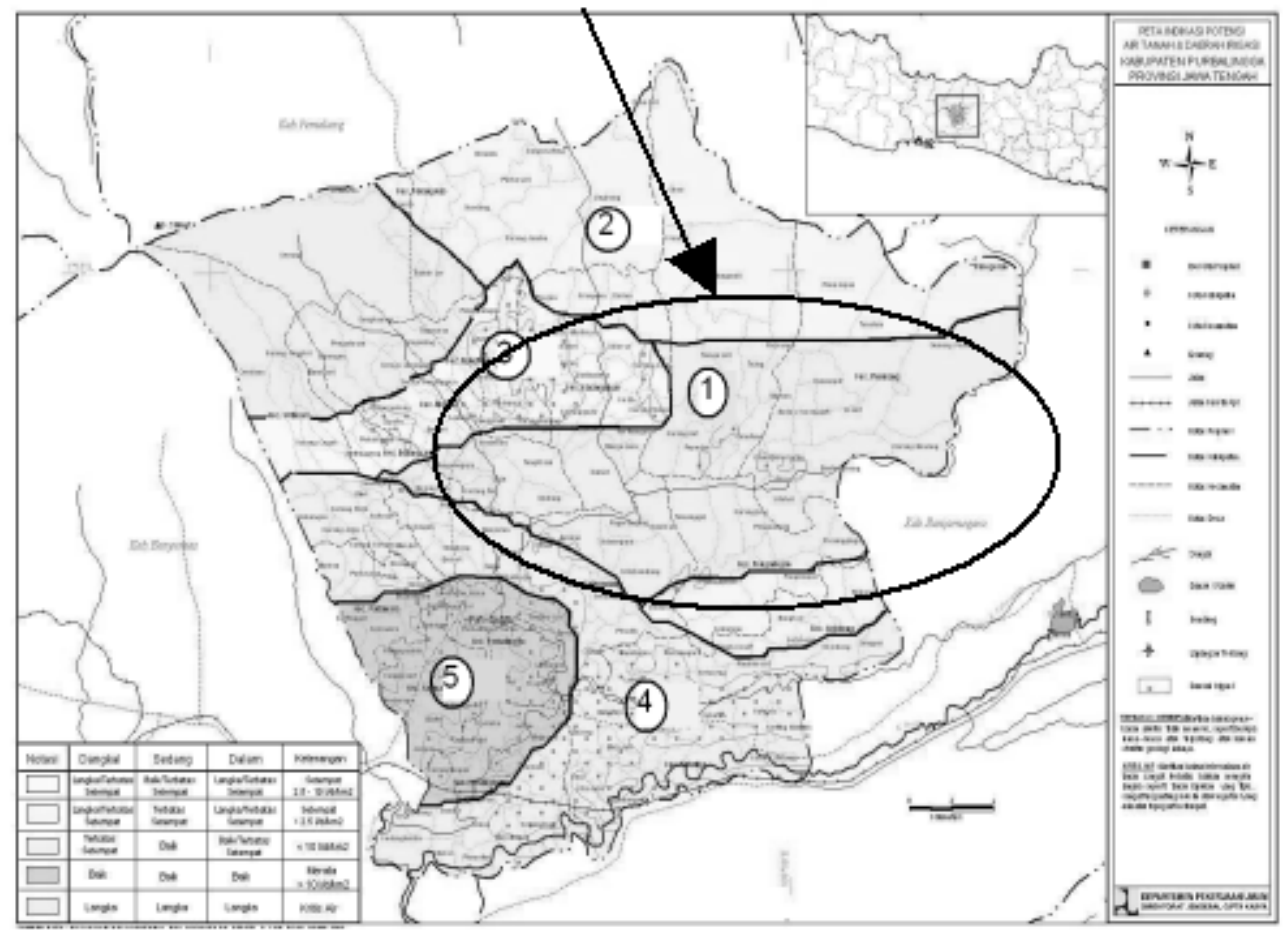

Gambar 6. Peta Indikasi Potensi Air Tanah di Kecamatan Pengadegan, (Data Dit.Jen.Cipta Karya Dep.PU), Tahun 2003,3). 
2. Potensi dan indikasi air tanah di lingkungan sekitar Waduk Puntuh Suruh

Potensi air tanah di Kecamatan Pengadegan berdasarkan peta indikasi hasil data penelitian dari Ditjen Cipta Karya Departemen Pekerjaan Umum (PU) ternyata pada umumnya lingkungan waduk Puntuk Suruh termasuk daerah dengan kategori langka air,

Dari peta diatas maka indikasi potensi air tanah di Kecamatan Pengadegan dapat dikategorikan seperti pada tabel berikut :

Potensi air tanah di Kecamatan Pengadegan termasuk kedalam kategori daerah tanda No. 1 yaitu air tanah dangkal, sedang dan dalam yang langka didapatkan. Hal ini berarti di daerah ini hampir semuanya merupakan lokasi yang sulit untuk mendapatkan air tanah. Di bagian barat yaitu pada tanda no.3 merupakan daerah yang masih bisa ditemukan sumber air dan lebih baik dari daerah 1 walaupun dengan jumlah yang terbatas dengan potensi sekitar 2,5 - 10 liter/detik/ km2.

Tabel 1. Indikasi Potensi Air Tanah*)

\begin{tabular}{|c|c|c|c|}
\hline \multirow{2}{*}{ No. } & \multicolumn{3}{|c|}{ Letak Air Tanah } \\
\hline & Dangkal & Sedang & Dalam \\
\hline \multirow{2}{*}{1.} & \multirow{2}{*}{ Langka } & \multirow{2}{*}{ Langka } & Langka \\
\hline & & & Krisis Air \\
\hline \multirow[t]{2}{*}{2.} & \multirow{2}{*}{$\begin{array}{l}\text { Langkai } \\
\text { Terbatas } \\
\text { setempat }\end{array}$} & \multirow{2}{*}{$\begin{array}{l}\text { Terbatas } \\
\text { Setempat }\end{array}$} & $\begin{array}{l}\text { Langkal } \\
\text { Terbatas } \\
\text { setempat }\end{array}$ \\
\hline & & & $\begin{array}{l}\text { Setermpat, } \\
<2,5 \\
\text { Lidetikm2 }\end{array}$ \\
\hline 3. & $\begin{array}{l}\text { Langkal } \\
\text { Terbatas } \\
\text { setempat }\end{array}$ & $\begin{array}{l}\text { Baiki } \\
\text { Terbatas } \\
\text { Setempat }\end{array}$ & $\begin{array}{l}\text { Setempat, } \\
<2,5-10 \mathrm{~L} \\
\text { idet/km2 }\end{array}$ \\
\hline \multirow[t]{2}{*}{4.} & \multirow{2}{*}{$\begin{array}{l}\text { Terbatas } \\
\text { setempat }\end{array}$} & \multirow[t]{2}{*}{ Baik } & $\begin{array}{l}\text { Baik } \\
\text { Terbatas } \\
\text { setempat }\end{array}$ \\
\hline & & & $\begin{array}{l}<10 \mathrm{~L} \\
\text { icttkm2 }\end{array}$ \\
\hline \multirow[b]{2}{*}{5.} & \multirow[b]{2}{*}{ Baik } & \multirow[b]{2}{*}{ Baik } & Baik \\
\hline & & & $\begin{array}{l}\text { Merata } \\
>10 \mathrm{~L} \\
\text { ictskm2 }\end{array}$ \\
\hline
\end{tabular}

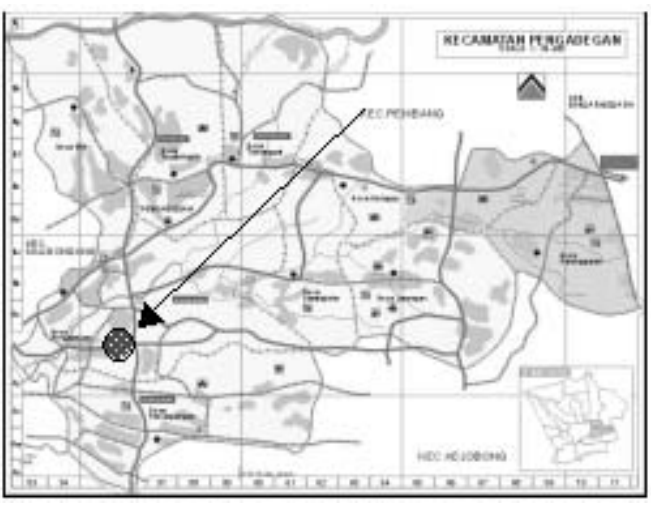

Gambar 7. Lokasi Pelaksanaan Imaging Resistivity di Desa Pengadegan Kecamatan Pengadegan, Purbalingga ${ }^{1)}$

(*).Catatan ; Data Peta Ditjen Ciptakarya,DPU. 
Hasil interpretasi dari pengukuran imaging resistivity yang telah dilakukan disekitar waduk Puntuk Suruh seperti pada Gambar 8 (terlampir).

Berdasarkan hasil penelitian di lapangan dan data pengukuran, terlihat bahwa secara keseluruhan terdapat tiga tempat potensial air yaitu a, b dan c. Air potensial yang ada relatif cukup dangkal dan tidak terlalu dalam. Luas dan bentuk dari ketiga lapisan potensial ini hampir sama satu dengan yang lain yaitu sama-sama pada daerah yang dangkal dan mencakup daerah luasan terbatas.

Lapisan potensi air yang di indikasikan terdapat di daerah penelitian dapat diuraikan seperti berikut :

1. Potensi A, yaitu pada titik (30 - 80) meter pada kedalaman $(10-40)$ meter dari permukaan. Potensi lapisan A ini 70 meter ke arah kiri waduk (sebelah barat). Tebal lapisan sekitar 20 meter dan cukup berpotensi didapatkan sumber air terbatas. Lapisan ini sebarannya kecil tidak luas ataupun menyebar. Lapisan ini diinterpretasikan merupakan daerah perangkap air pada waktu musim hujan dan diperkirakan apabila pada musim kemarau menjadi berkurang karena tidak ada suplai air dari turunnya hujan.

2. Potensi B, yaitu pada titik $(150-190)$ meter, sekitar kedalaman $(0-20)$ meter dari permukaan. Lokasi lapisan ini diperkirakan terdapat di dekat lapisan permukaan. Tebal lapisan ini di perkirakan 20 meter yang memanjang sekitar 30 - 40 meteran. Lapisan potensi B terletak ditengah daerah pengukuran dan diperkirakan lapisan ini tidak menyebar luas dan terbatas. Sama seperti potensi A maka lapisan ini diperkirakan hanya tempat perangkap air dan suplainya terbatas.

3. Potensi $\mathbf{C}$, yaitu potensi lapisan yang terletak di sebelah barat (kanan) memanjang pada titik sekitar (240 -
275) meter, lapisan ini berada dikedalaman antara $(10-25)$ meter dan relatif dekat permukaan. Lapisan potensi ini hampir sama dengan kondisi lapisan lain yang tidak menerus dan tidak meluas serta terbatas.

Selain lapisan air di atas ternyata disekitar daerah terdapat lapisan lainnya yaitu :

1. Lapisan $D$, yang diinterpretasikan sebagai lapisan yang lebih keras yang berada disepanjang titik (50 - 150 meter) dengan ketebalan yang bervariasi antara $10-25$ meter. Lapisan ini terletak di atas lapisan potensial A dan sebagian lapisan potensial B. Jadi dapat dikatakan pada sisi barat (kiri) daerah penelitian bukan daerah potensial air yang besar karena sebagian daerah terletak pada daerah lapisan yang cukup keras.

2. Lapisan $\mathrm{E}$, yang terletak pada titik 90 - 180 meter, kedalaman 40 - > 100 meter yang tepat dibawah lapisan B. Lapisan ini diperkirakan sebagai lapisan yang cukup keras (bukan lapisan potensial air) yang cukup dalam yaitu pada sisi barat (kiri) daerah penelitian.

Dari dua lapisan D dan E dapat dikatakan bahwa pada lokasi sebelah Barat daerah penelitian ini diperkirakan bukan merupakan daerah potensial air sebagai sumber dari waduk karena lapisan potensial Dengan kata lain bahwa endapan potensil air cukup kecil dan berada di atas lapisan yang lebih keras.

Potensi air pada lokasi sebelah timur waduk ternyata lebih potensial dibandingkan dengan sisi barat. Di lokasi ini terdapat potensi lapisan air $B$ dan $C$ yang memang tidak terlalu luas dan tidak bersambungan (terpisah) satu dengan yang lain. Pada daerah (sisi) ini dibawah lapisan potensial air diinterpretasikan tidak terdapat lapisan yang lebih keras seperti pada lokasi sebelah 
barat. Lokasi ini memang menjadi cukup potensial walaupun diperkirakan hanya sebagai daerah tangkapan air mengingat sebarannya hanya setempat dan tidak luas.

\section{KESIMPULAN}

Berdasarkan analisis dan pemodelan serta pengamatan di lapangan didapatkan beberapa kesimpulan, antara lain :

1. Data hasil pengamatan secara umum daerah penelitian bercurah hujan tinggi pada bulan Desember dan terendah pada bulan Agustus. Berdasarkan peta indikasi potensi air tanah di Kecamatan Pengadegan ternyata termasuk kedalam kategori daerah tanda No. 1 yaitu air tanah dangkal, sedang dan dalam yang langka didapatkan. Hal ini berarti di daerah ini hampir semuanya merupakan lokasi yang sulit untuk mendapatkan air tanah.

2. Hasil interpretasi di daerah penelitian didapatkan 3 lokasi potensi air tanah dangkal di sebelah Barat lokasi (sisi) sebelah kiri daerah waduk. Lokasi lainnya yaitu 2 lapisan potensi lainnya yang di interpretasikan sebagai endapan yang lebih keras dan bukan daerah potensi air tanah, yang terdapat disebelah Timur (kanan) dari waduk.

3. Potensi lapisan terdapat di tiga tempat yaitu $A, B$ dan $C$ yang berada disisi sebelah Barat dari waduk berada dikedalaman yang cukup dangkal bervariasi dari $0-40$ meter yang tidak terlalu luas dan terbatas (tidak bersambungan) satu dengan yang lain. Dengan kata lain bahwa endapan potensi ini tidak terlalu besar apalagi lapisan tersebut juga berada di atas lapisan endapan yang lebih keras ( Potensi C dan D). Sedangkan lokasi sebelah Timur (B dan $C$ ) daerah waduk cukup berpotensi walaupun tidak terlalu luas dan berada di lokasi yang cukup dangkal.

Secara umum diperkirakan dari semua lapisan potensi yang ada merupakan lokasi lapisan tangkapan air dan jumlah air yang ada akan sangat tergantung kepada suplai air dari musim hujan.

4. Lokasi potensial yang diperlukan harus terus di cari dan diteliti dilokasi sebelah timur waduk. Hal ini perlu dilakukan agar diperoleh sumber air yang potensial sehingga waduk tidak ada akan kekurangan air.

\section{DAFTAR PUSTAKA}

1. Dinas Pertanian dan Kehutanan ,"Buku Petanian Dalam Angka 2005 Kabupaten Purbalingga”, 2006 Purbalingga.

2. BPPT,"Laporan Aplikasi Res 2 D untuk survei air bawah tanah di kabupaten Purbalingga”, 2005, Jakarta.

3. Departemen PU, "Peta Indikasi Potensi air Tanah" Dirjen Cipta Karya, 2003, Jakarta.

4. Model Praktikum GL-645,"Praktikum Pengukuran Geofisika, 1996, Lab. Fisika Bumi, Jurusan Fisika, ITB.
Barat
Titik Tengah
Timur

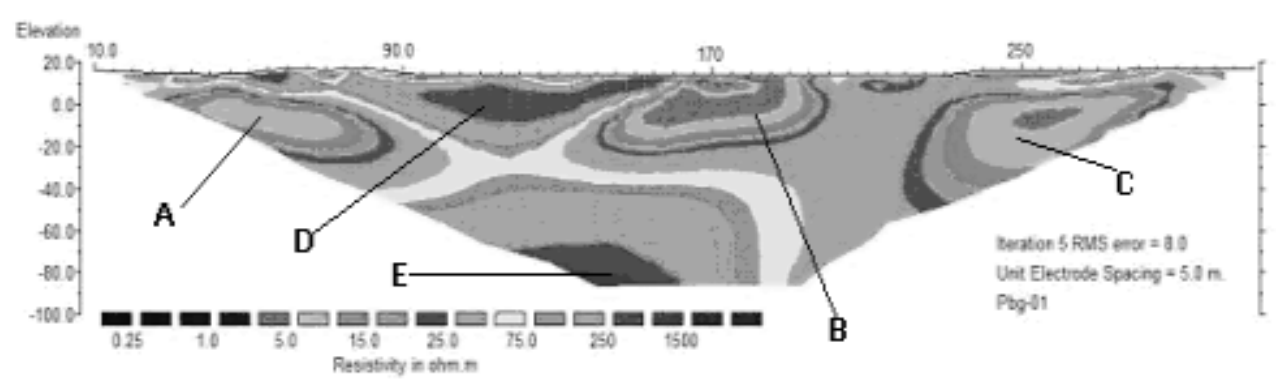

Gambar 8. Lokasi dan hasil Imaging resistivity di waduk Puntuk Suruh 